\title{
PENGARUH CASH RATIO, DEBT TO EQUITY RATIO, DAN RECEIVABLE TURNOVER TERHADAP RETURN ON ASSETS PADA PERUSAHAAN MAKANAN DAN MINUMAN YANG TERDAFTAR DI BURSA EFEK INDONESIA PERIODE 2014-2018
}

\author{
RAFIDA KHAIRANI, KRISTIANUS BUULOLO, MESRA JULIANA, YOSEPH SETIAWAN ZAI \\ Universitas Prima Indonesia \\ Email: rafidakhairani256@gmail.com, kristianuslolo1996@gmail.com, \\ mesrajuliana@gmail.com, yosephzai1998@gmail.com
}

(Article History)

Received October 06, 2020; Revised November 05, 2020; Accepted November 06, 2020

\begin{abstract}
:
The increased of cash ratio, debt to equity, receivable turnover is not always followed by an increase and decrease in return on assets. Using that statement as the background of this study, this study is conducted to test the influence of cash ratio, debt to equity, receivable turnover on return on assets. The data collection techniques in this study were conducted using documentation techniques with a sample count of twenty-three (23) and one hundred three (103) populations in food and beverage companies listed on the Indonesia Stock Exchange for the period 2014-2018 using multiple linear analysis techniques. The benefit of the results of this study is a consideration for companies and the next researcher about the variables used in this study. Based on the results of the study can be partially concluded cash ratio, debt to equity, receivable turnover negatively effects on the return on assets and simultaneously positively effects on the return on assets in food and beverage companies listed on the Indonesia Stock Exchange for the period 2014-2018.
\end{abstract}

Keywords: Cash Ratio, Debt to Equity Ratio, Receivable Turnover, Return on Assets

\section{PENDAHULUAN}

$\mathrm{T}$ ingkat pengembalian terhadap modal suatu perusahan dapat diukur dengan rasio investasi atau Return on Assets (ROA) yang dapat mengetahui efektifitas dan efesiensi aset perusahaan menghasilkan keuntungan (laba). Bila laba yang dihasilkan cukup besar maka perusahaan memberikan tingkat pengembalian yang signifikan. Sementara rasio yang mengukur kewajiban perusahaan (utang) ialah Cash Ratio (CR) dimana total kas atau setara kas dibandingkan dengan utang lancarnya. Debt to equity adalah alat ukur suatu jumlah jaminan yang tersedia kepada penagih. Sedangkan receivable turnover digunakan untuk mengetahui seberapa besar perputaran piutang dari penjualan, dengan kata lain semakin sering piutang berputar, maka keuntungan yang akan diperoleh semakin besar.

Hasil pra observasi pada Tabel 1 menjadi rujukan masalah penelitian, untuk menguji apakah terdapat pengaruh cash ratio $(C R)$, debt to equity, dan receivable 
turnover terhadap ROA pada perusahaan makanan dan minuman yang terdaftar di Bursa Efek Indonesia (BEI) periode 2014-2018.

Tabel 1. Hasil Olah Data Perusahaan

\begin{tabular}{|c|c|c|c|c|c|c|}
\hline Tahun & $\begin{array}{l}\text { Nama } \\
\text { Perusahaan }\end{array}$ & $\begin{array}{l}\text { Cash } \\
\text { Ratio }\end{array}$ & $\begin{array}{l}\text { Debt to } \\
\text { Equity }\end{array}$ & $\begin{array}{l}\text { Receivable } \\
\text { Turnover }\end{array}$ & $\begin{array}{l}\text { Return } \\
\text { on } \\
\text { Assets }\end{array}$ & Keterangan \\
\hline 2015 & PT Delta & 3.52 & & & 0.18 & Menunjukkan \\
\hline 2016 & Djakarta Tbk & 4.77 & & & 0.21 & $\begin{array}{l}\text { ketidaksamaan pada } \\
\text { dasar teori dimana nilai } \\
\text { ROA menurun jika cash } \\
\text { ratio naik }\end{array}$ \\
\hline 2016 & PT Akasha Wira & & 0.18 & & 0.07 & Menyimpang pada dasar \\
\hline 2017 & $\begin{array}{l}\text { International } \\
\text { Tbk }\end{array}$ & & 0.10 & & 0.04 & $\begin{array}{l}\text { teori, seharusnya nilai } R O A \\
\text { naik jika debt to equity } \\
\text { turun }\end{array}$ \\
\hline 2014 & PT Wilmar & & & 0.03 & 0.03 & Tidak mengarah pada \\
\hline 2015 & $\begin{array}{l}\text { Cahaya } \\
\text { Indonesia Tbk }\end{array}$ & & & 0.01 & 1.07 & $\begin{array}{l}\text { dasar teori dimana } R O A \\
\text { ikut turun jika receivable } \\
\text { turnover menurun }\end{array}$ \\
\hline
\end{tabular}

Sumber: Data diolah, 2020

Adapun pengertian masing-masing variabel dan keterkaitan antara cash ratio $(C R)$, debt to equity, dan receivable turnover terhadap return on assets (ROA) dapat dilihat menurut para ahli dan hasil penelitian yang telah dikutip, berikut ini:

Menurut Sawir (2012), "Cash ratio merupakan rasio yang dapat digunakan untuk melihat jumlah kas yang ada untuk membayar utang perusahaan". Menurut Kasmir (2012, h. 138), "Cash ratio dapat dijadikan tolak ukur perusahaan melihat kemampuan kas yang tersedia membayar utang". Perhitungan CR adalah kas ditambah sekuritas dibagi utang lancar. Menurut Suguono dan Untung (2016) "ROA adalah kemampuan seluruh aktiva menghasilkan laba". Menurut Hery (2017, h. 314) "Perhitungan $R O A$ ialah laba bersih dibagi total aset, tingginya suatu modal dapat menentukan nilai keutungan yang didapat. Menurut Sudana (2011), "Receivable turnover adalah rasio perputaran piutang yang dapat mengukur efektifitas piutang dalam menghasilkan laba". Menurut Yudiana (2013, h. 77), "Receivable turnover dapat diketahui dengan membagikan jumlah credit sales pada periode tertentu dengan total rata-rata piutang". Menurut Jusuf (2014), "Debt to equity ratio merupakan perbandingan kemampuan perusahaan membayar total kewajibannya dengan total modal sendiri (equity)".

Perhitungan debt to equity adalah total kewajiban dibagi modal sendiri. Kasmir (2012, h. 157) mendefinisikan "Debt to equity ratio adalah penilaian utang atas modal yang ada". Yuniastuti (2016) dalam penelitiannya menemukan bahwa cash ratio berpengaruh dominan terhadap return on assets. Namun di sisi lain Putri (2020) menemukan bahwa cash ratio tidak berpengaruh langsung terhadap ROA. Selanjutnya, hasil penelitian Putri dan Triayarti (2013) menemukan bahwa cash ratio berpengaruh negatif signifkan terhadap ROA. Berdasarkan hasil yang berbeda ini, peneliti menyimpulkan bahwa cash ratio tidak berpengaruh langsung terhadap $R O A$. 
Kusumajaya (2011) menyatakan bahwa pemilihan sumber dana (DER) yang tepat akan mempengaruhi profitabilitas perusahaan $(R O A)$, dimana $D E R$ meningkat maka kemampuan perusahaan memperoleh laba akan semakin rendah sehingga $D E R$ berpengaruh negatif terhadap $R O A$. Penelitian yang dilakukan Indrawan, dkk (2014) menemukan bahwa DER berpengaruh dan signifikan terhadap ROA. Penelitian Alfarizi dan Muid (2014) menemukan bahwa DER berpengaruh negatif dan signifikan terhadap ROA. Mahardhika dan Marbun (2016) menemukan bahwa $D E R$ berpengaruh negatif signifikan terhadap $R O A$. Hal ini yang mendorong peneliti untuk meneliti $D E R$ terhadap $R O A$ pada perusahaan makanan dan minuman yang terdaftar di Bursa Efek Indonesia periode 2014-2018 untuk memberikan manfaat sebagai pertimbangan bagi perusahaan dan peneliti selanjutnya.

Umayta, dkk (2019) pada penelitianya menemukan bahwa receivable turnover tidak berpengaruh terhadap $R O A$, sehingga dapat disimpulkan bahwa pada penelitian ini receivable turnover tidak berpengaruh langsung terhadap return on assets pada perusahaan makanan dan minuman yang terdaftar di Bursa Efek Indonesia periode 2014-2018.

Berdasarkan uraian teori dan penelitian sebelumnya yang memiliki perbedaan mendorong peneliti untuk melakukan kajian pengaruh cash ratio, debt to equity ration, dan receivable turnover terhadap return on assets pada perusahaan makanan dan minuman yang terdaftar di Bursa Efek Indonesia periode 2014 -2018, yang mana hasil penelitian ini dapat menjadi rujukan dan sebagai bahan pertimbangan bagi perusahaan dan peneliti berikutnya.

\section{METODE PENELITIAN}

Peneliti melakukan pengkajian pada perusahaan makanan dan minuman yang terdaftar di BEI, lewat situs www.idx.co.id. Peneliti menggunakan metode kuantitatif dalam penelitian ini. Tujuannya adalah menemukan hubungan sebab akibat antara independent variable $(\mathrm{X})$ terhadap dependent variable $(\mathrm{Y})$. Populasi penelitian merupakan data keuangan perusahaan makanan dan minuman di BEl periode 2014-2018 sebanyak dua puluh enam (26) populasi. Teknik pengambilan sampel penelitian adalah purposive-sampling yaitu tipe pemilihan sampel berdasarkan pertimbangan tujuan penelitian. Dari hasil pemilihan sampel dengan metode purposive sampling terdapat 23 perusahaan yang sesuai kriteria dari keseluruhan populasi sebanyak 26 perusahaan. Jadi, total jumlah sampel sebanyak 92 data perusahaan setelah dikalikan 4 (empat) tahun. Pengumpulan data yang digunakan adalah teknik informasi sekunder melalui dokumentasi laporan keuangan perusahaan yang terdaftar di BEI periode 2014 - 2018. Teknik analisis data dalam pengujian ini menggunakan uji asumsi klasik yang terdapat empat (4) bagian pengujian dalam model regresi antara lain, Untuk menyelidiki variable pengganggu telah terdistribusi normal atau sebaliknya menggunakan uji normalitas, Untuk menyelidiki terdapat atau tidak distingsi varians dengan residual 1 peninjauan pada 
peninjauan lainnya menggunakan uji heteroskedastisitas. Untuk menyelidiki terjadi atau tidak interelasi antar independent variable atau tidak menggunakan uji multikoloniearitas, Untuk menyelidiki terdapat atau tidak distingsi antar kesalahan pengganggu dari fase t ke fase t-1 (sebelumnya) menggunakan uji autokorelasi. Pada pengujian ini, penelitian dilakukan dengan analisis regresi linear berganda memakai model penelitian, yakni:

$$
Y=a+b_{1} X_{1}+b_{2} X_{2}+b_{3} X_{3}+e
$$

Keterangan: $\mathrm{Y}=$ Return on Assets, $\mathrm{a}=$ Konstanta, $\mathrm{X}_{1}=$ Cash Ratio, $\mathrm{X}_{2}=$ Debt to Equity, $\mathrm{B}_{1} \mathrm{~b}_{2} \mathrm{~b}_{3}=$ Koefisien Regresi, $\mathrm{X}_{3}=$ Receivable Turnover, dan $\mathrm{e}=$ Kekeliruan (error)

Sedangkan untuk pengujian kemampuan independent variable menjelaskan dependent variable dapat digunakan uji koefisien determinasi $\left(R^{2}\right)$. Untuk menjelaskan seberapa besar independent dijelaskan oleh seluruh dependent adalah menggunakan uji $\mathrm{F}$ dan untuk menyelidiki signifikan pengaruh dari beberapa independent $\left(\mathrm{X}_{1} \mathrm{X}_{2} \mathrm{X}_{3}\right)$ terhadap dependent $(\mathrm{Y})$ menggunakan uji statistik (uji t).

\section{HASIL PENELITIAN DAN PEMBAHASAN}

\section{Paparan Umum Bursa Efek Indonesia (BEI) \& Perusahaan}

BEI merupakan pasar modal yang dapat memberikan peluang investasi serta permodalan bagi seluruh lapisan masyarakat Indonesia untuk turut serta mendukung perekonomian nasional. Penelitian ini menguji Pengaruh independent variable dengan dependent variable pada perusahaan makanan dan minuman di $\mathrm{BEI}$, dengan tahun penelitian adalah terdiri dari lima (5) tahun dengan dua puluh tiga (23) sampel perusahaan, maka observasi dalam penelitian ini berjumlah seratus tiga (103) observasi data perusahaan.

\section{Statistik Deskriptif}

Statistik deskriptif adalah model penyajian data berupa nilai minimum, maximum, rata-rata (mean) dan standar deviasi.

\section{Tabel 2. Statistika Dekriptif}

\begin{tabular}{|c|c|c|c|c|c|}
\hline \multicolumn{6}{|c|}{ Descriptive statictics } \\
\hline & $\mathrm{N}$ & Minimum & Maximum & Mean & Std. Deviation \\
\hline LnCR & & .00 & 5.55 & 3.0572 & 1.62045 \\
\hline LnDER & & .69 & 4.41 & 3.4393 & .91108 \\
\hline LnRT & & 1.61 & 10.53 & 6.6718 & 1.49299 \\
\hline LnROA & & .00 & 5.45 & 1.8424 & 1.10244 \\
\hline Valid N (listwise) & & & & & \\
\hline
\end{tabular}

Sumber: Data diolah, 2020

Bersumber dari output pada Tabel 2 disimpulkan bahwa cash ratio dengan jumlah sampel 103, nilai minimum 0.00 kali diperoleh oleh PT. Ultrajaya Milk Industry and Trading Campany, Tbk. nilai maximum 5.55 kali bagi PT. Unilever Indonesia, Tbk. dengan mean 3.0752 dan std. deviation 1.62045. Debt to equity dengan jumlah 
sampel 103, nilai minimum 0.69 kali dari PT. Akasha Wira International, Tbk. Nilai maximum 4.41 kali dari PT. Sekar Laut, Tbk. dengan mean 3.4393 dan std. deviation 0.91108. Receivable turnover dengan jumlah sampel 103, nilai minimum $1.61 \mathrm{kali}$ pada PT. Mandom Indonesia, Tbk. Nilai maximum 10.53 kali pada PT. Tempo Scan Pacific, Tbk. dengan mean 6.6718 dan std. deviation 1.49299. Return on assets dengan jumlah sampel 103, terdapat 0.00 kali nilai minimum di PT. Wismilak Inti Makmur, Tbk. maximum 5.45 kali pada PT. Akasha Wira International, Tbk. dengan mean 1.8424 dan 1.10244.

\section{Hasil Uji Asumsi Klasik}

Berdasarkan hasil uji normalitas melalui teknik analisis grafik bahwa data telah terdistribusi normal, dengan dibuktikan pada grafik histogram yang mengikuti kurva membentuk lonceng tidak bergeser ke kiri atau ke kanan. Sedangkan hasil uji normalitas melalui teknik normal probability plot bahwa telah terdistribusi normal yang dapat dilihat, data menyebar mengikuti garis diagonal.

Tabel 3. Hasil Uji asumsi klasik

\begin{tabular}{|c|c|c|c|c|c|}
\hline \multirow[t]{2}{*}{ Model } & \multirow[t]{2}{*}{$\begin{array}{c}\text { Uji } \\
\text { normalitas }\end{array}$} & \multicolumn{2}{|c|}{$\begin{array}{c}\text { Uji } \\
\text { Multikoloniearitas }\end{array}$} & \multirow[t]{2}{*}{$\begin{array}{c}\text { Uji } \\
\text { Autokorelasi }\end{array}$} & \multirow{2}{*}{$\begin{array}{c}\text { Uji } \\
\text { Heteroskedastisitas } \\
\text { Sig. }\end{array}$} \\
\hline & & Tolerance & VIF & & \\
\hline $\begin{array}{l}\text { Durbin- } \\
\text { watson }\end{array}$ & & & & 1.891 & \\
\hline LnCR & & .524 & 1.908 & & .923 \\
\hline LnDER & & .670 & 1.492 & & .130 \\
\hline LnRT & & .636 & 1.573 & & .377 \\
\hline
\end{tabular}

Sumber: Data diolah, 2020

Output pada Tabel 3 Menyimpulkan bahwa, uji normalitas melalui model nonparametric kolomogorov-smirnov (K-S) yang ketentuannya adalah nilai sig. > 0,05, maka data telah terdistribusi dengan normal ataupun sebaliknya. Jika dilihat pada Tabel 3 nilai sig. $0.864>0,05$, maka data terdistribusi dengan normal secara signifikan. Uji multikoliniearitas melalui penentuan kriteria bahwa nilai variance factor (VIF) $\leq 10$ dan tolerance $\geq 0,10$, berarti regresi tidak terjadi multikoliniearitas. Seperti hasil pada Tabel 3 terdapat $0.524 \geq 0,10$, nilai tolerance pada cash ratio $\left(\mathrm{x}_{1}\right)$, $0.670 \geq 0,10$ pada debt to equity $\left(\mathrm{x}_{2}\right), 0.636 \geq 0,10$, dan terdapat $1.908 \leq 10$ nilai VIF pada cash ratio $\left(\mathrm{x}_{1}\right), 1.492 \leq 10$ pada debt to equity $\left(\mathrm{x}_{2}\right), 1.573 \leq 10$ pada receivable turnover, maka disimpulkan bahwa tidak terjadi multikoloniearitas pada data, uji autokorelasi melalui teknik uji Durbin-Watson dengan kriteria nilai dW yang akan dibandingkan 2 (dua) dW tabel yaitu, Durbin-Upper (dU) dan Durbin-Lower (dL). Dari Tabel 3. di atas terdapat hasil 1.891 pada Durbin-Watson, sedangkan nilai dW tabel dengan signifikan 0,05, adalah dU 1.6196 \& dL 1.7392, sehingga disimpulkan bahwa data bebas autokorelasi, uji heteroskedastisitas dengan menggunakan uji glejser bermaksud meregresi nilai yang mutlak residual pada independent variable, 
dengan tujuan mendeteksi apakah terdapat heteroskedastisitas atau sebaliknya (homokedastisitas). Sesuai output dari Tabel 3 bahwa model regresi bebas dari heterokedastisitas dengan nilai signifikan variabel cash ratio sebesar 0.923 , nilai debt to equity 0.130 , dan receivable turnover 0.377 . Hasil dari ketiga variabel independent $>0,05$ (sig > 0,05).

Hasil Analisis Data

Tabel 4. Hasil Analisis Data

\begin{tabular}{|c|c|c|c|c|c|c|}
\hline \multirow[t]{2}{*}{ Model } & \multirow{2}{*}{$\begin{array}{c}\text { Uji Regresi } \\
\text { Linear } \\
\text { Berganda } \\
\text { B }\end{array}$} & \multirow{2}{*}{$\begin{array}{l}\text { Uji Koefisien } \\
\text { Determinasi } \\
\qquad\left(\mathrm{R}^{2}\right) \\
\text { Adjusted } R \\
\text { Square }\end{array}$} & \multicolumn{2}{|c|}{$\begin{array}{c}\text { Uji Hipotesis } \\
\text { secara Simultan } \\
\text { (uji F) }\end{array}$} & \multicolumn{2}{|c|}{$\begin{array}{c}\text { Uji Statistik } \\
\text { secara Parsial } \\
\text { (uji t) }\end{array}$} \\
\hline & & & $F$ & Sig. & $\mathrm{t}$ & Sig. \\
\hline (Constant) & 2.682 & .060 & 3.176 & $0.27^{b}$ & & \\
\hline LnCR & -.139 & & & & -1.542 & .126 \\
\hline LnDER & .138 & & & & .974 & .333 \\
\hline LnRT & -.133 & & & & -1.500 & .137 \\
\hline
\end{tabular}

Sumber: Data diolah, 2020

Berdasarkan output pada SPSS pada Tabel 4, pada uji regresi linear berganda terdapat persamaan regresi, yaitu:

$$
\text { LnROA=2,682 - 0,139 LnCR + 0,138 LnDER - 0,133LnRT }
$$

Dengan interpretasi nilai Koefisien variabel terikat memiliki nilai (beta) 2.682, sehingga nilai variabel bebas adalah 0 (nol), Koefisien cash ratio memperoleh nilai 0.139 bersimbol negatif, artinya penurunan yang terjadi pada cash ratio akan meningkatkan return on assets sebesar 0.139 , Nilai koefisien debt to equity terdapat 0.138 , artinya peningkatan debt to equity akan meningkatkan 0.138 pada return on assets, Koefisien receivable turnover memperoleh nilai 0.133 bersimbol negatif, artinya penurunan yang terjadi pada receivable turnover akan terjadi penurunan pada return on assets sebesar 0.133 .

Pada Tabel 4 kemampuan independent variable menjelaskan dependent variable melalui uji koefisien determinasi dengan hasil Adjusted $R$ Square diperoleh 0.60 artinya kemampuan variabel independent $(\mathrm{x})$ menjelaskan dependent $(\mathrm{y})$ adalah $6 \%$, sedangkan sisanya $94 \%$ dapat dijelaskan pada variabel di luar model penelitian. Dalam menguji kemampuan independent menjelaskan dependent dengan melakukan uji hipotesis secara simultan (uji F) pada hasil olah data di Tabel 4, yaitu $F_{\text {hitung }} 3.176>F_{\text {tabel }} 2.70$ dengan signifikan $0.027<0.05$, maka dapat disimpulkan bahwa Ho ditolak Ha diterima yang berarti cash ratio, debt to equity, dan receivable turnover secara simultan berpengaruh terhadap return on assets pada perusahaan makanan \& minuman yang terdaftar di BEI periode 2014-2018.

Sedangkan untuk mengetahui pengaruh variabel independent terhadap variabel dependent menggunakan uji statistik (uji t) pengolahan data, diperoleh uji 
statistik dengan interpretasi hasil pada Tabel 4 bahwa nilai cash ratio adalah thitung $1.654<t_{\text {tabel }} 1.98422$ dengan signifikasi $0.126>0.05$, maka disimpulkan cash ratio menurut parsial tidak berpengaruh langsung terhadap ROA, dan Ho ditolak $\mathrm{Ha}$ diterima. Kesimpulannya bahwa pengaruh jumlah kas yang ada pada perusahaan tidak mempengaruhi langsung terhadap laba perusahaan yang diperoleh. Hasil penelitian ini sependapat dengan peneliti terdahulu diantaranya Putri dan Triayarti (2013) bahwa cash ratio berpengaruh negatif signifikan terhadap ROA. Selanjutnya, Putri (2020) menemukan bahwa cash ratio tidak berpengaruh langsung terhadap ROA. Hasil penelitian yang berbeda oleh Yuniastuti (2016) bahwa cash ratio berpengaruh dan dominan terhadap ROA. Nilai pada debt to equity adalah thitung $0.974<t_{\text {tabel }} 1.98422$ dengan signifikasi $0.333>0.55$, maka disimpulkan debt to equity menurut parsial tidak berpengaruh langsung terhadap ROA, dan Ho ditolak $\mathrm{Ha}$.

Kesimpulannya bahwa pengaruh modal tidak mempengaruhi secara langsung terhadap perolehan laba perusahaan, pada penelitian ini sejalan dengan peneliti terdahulu seperti Alfarizi dan Muid (2014) bahwa DER berpengaruh negatif dan signifikan terhadap ROA. Namun berbeda dengan hasil penelitian Indrawan, dkk (2018) yang menemukan bahwa DER berpengaruh signifikan terhadap $R O A$, dan Yuniastuti (2016) DER berpengaruh dan dominan terhadap ROA.

Nilai receivable turnover adalah $t_{\text {hitung }}-1.500<t_{\text {tabel }} 1.98422$ dengan signifikasi 0.137 > 0.05, maka disimpulkan receivable turnover secara parsial tidak berpengaruh langsung terhadap $R O A$, dan Ho ditolak Ha diterima. Kesimpulannya bahwa pengaruh perputaran piutang perusahaan tidak mempengaruhi secara langsung dalam menghasilkan laba perusahaan. Hasil penelitian ini tidak sejalan dengan penelitian sebelumnya Anggadini dan Rajiman (2015) menyatakan bahwa receivable turnover berpengaruh positif signifikan terhadap $R O A$, dan penelitian Kamal (2016) yang menemukan bahwa receivable turnover berpengaruh tidak signifikan terhadap ROA. Namun sejalan dengan beberapa penelitian terdahulu, yaitu Umayta, dkk (2019) pada penelitiannya bahwa receivable turnover tidak berpengaruh terhadap $R O A$. Dari hasil penelitian ini, peneliti dapat menyimpulkan bahwa secara parsial cash ratio, debt to equity ratio, dan receivable turnover tidak berpengaruh langsung terhadap return on assets pada perusahaan makanan dan minuman yang terdaftar di Bursa Efek Indonesia periode 2014-2018.

\section{PENUTUP/SIMPULAN}

Sesuai hasil pada pengujian ini dapat disimpulkan bahwa secara parsial (uji t) cash ratio, debt to equity, dan receivable turnover tidak berpengaruh terhadap $R O A$ pada perusahaan makanan dan minuman yang terdaftar di BEI. Sedangkan hasil uji secara simultan (uji F) bahwa independent variable berpengaruh terhadap dependent variable pada perusahaan makanan dan minuman yang terdaftar di BEl. Hasil penelitian pada uji regresi linear berganda terdapat bahwa cash ratio berpengaruh 
negatif dan signifikan terhadap $R O A$, dan debt to equity berpengaruh negatif dan signifikan terhadap $R O A$, sedangkan receivable turnover berpengaruh positif terhadap $R O A$. Hasil penelitian dari uji koefisien determinasi $\left(\mathrm{R}^{2}\right)$ bahwa kemampuan cash ratio, debt to equity, dan receivable turnover mengungkapkan ROA sebesar $6 \%$ dan 94\% sisanya dapat diungkapkan diluar metode pada penelitian ini.

Bagi pengusaha disarankan agar mengamati peningkatan laba perusahaan dengan memperhatikan cash ratio, debt to equity, dan receivable turnover serta variabel lain yang signifikan terhadap $R O A$, dan bagi peneliti berikutnya agar memakai variable selain dari penelitian ini dan mengganti objek penelitian, misalnya perusahaan selain makanan dan minuman di BEl.

\section{DAFTAR PUSTAKA}

Anggadini, Sri Dewi, dan Rajiman, Imam. (2015). Pengaruh Perputaran Piutang dan Struktur Modal terhadap Profitabilitas (pada Perusahaan Pembiayaan yang terdaftar di Bursa Efek Indonesia Tahun 2009-2013). Universitas Komputer Indoneisa https://elib.unikom.ac.id/files/disk1/699/jbptunikompp-gdlimamrajima-34929-10-unikom_i-I.pdf

Alfarizi, Cahya Utama. dan Muid, Dull. (2014). Pengaruh Current ratio, Debt to equity ratio, Debt asset ratio, dan Perputaran modal kerja terhadap Return on Assets pada perusahaan manufaktur yang terdaftar di Bursa Efek Indonesia periode 2010-2012. Diponegoro Jurnal Accounting. 3(2). 41-53. https://ejournal3.undip.ac.id/index.php/accounting/article/view/6085

Hery. (2017). Analisis Laporan Keuangan dan Edisi Komperensif. Jakarta: Grasindo. Jusuf. (2014). Analisis Kredit untuk Akuntansi. Jakarta: PT. Granmedia.

Kamal, M.Basri. (2016). Pengaruh Receivable Turnover dan Debt to Equity Ratio (DAR) terhadap Return on Assets (ROA) pada Perusahaan Pertanian yang terdaftar di Bursa Efek Indonesia (BEI). Jurnal IImiah Manajemen dan Bisnis. 17(2). 68-81. DOI: 10.30596/jimb.v17i2.996

Kasmir. (2012). Analisis Laporan Keuangan (Kelima). Jakarta: Rajawali Pers.

Kusumajaya, Dewa Kadek Oka. (2011). Pengaruh Struktur Modal dan Pertumbuhan Perusahaan terhadap Profitabilitas dan Nilai Perusahaan Manufaktur di Bursa Efek Indonesia. Tesis (S2). Universitas Udayana.

Mahardhika, PA. dan Marbun, Dahar. (2016). Pengaruh Current Ratio dan Debt To Equity terhadap Return on Assets. Journal of Pembangunan Jaya University. 3(Maret 2016). 23-28. https://doi.org/10.36262/widyakala.v3i0.21

Putri, Andiena Nindya. dan Triayarti, Nyoman. (2013). Pengaruh Likuiditas (Cash Ratio) dan Loan to Deposit Ratio terhadap Profitabilitas Asset (ROA) pada Sektor Perbankan yang Tercatat di Bursa Efek Indonesia Periode 2008 - 
2012. E-Jurnal Manajemen. 2(10).

$1333-1345$

https://ojs.unud.ac.id/index.php/Manajemen/article/view/5781

Putri, Shadina Arika. (2020). Pengaruh Cash Ratio (CR), dan Loan to Deposito Ratio (LDR) Terhadap Return on Assets (ROA) pada Perusahaan Perbankan yang Terdaftar di Bursa Efek Indonesia Tahun 2017-2019. Tesis (S2). Universitas Tridinanti Palembang. http://repository.univ-tridinanti.ac.id/1416/

Indrawan, Andri, dan Rohayati, Sitti. (2018). Pengaruh Debt to Equity Ratio terhadap Return on Assets (ROA) pada Perusahaan Sub Sektor Farmasi yang Terdaftar di Bursa Efek Indonesia. UMMI: Jurnal Penelitian dan Pengembangan Sains dan Teknologi, XII(3). 5-16.

Sawir, A. (2012). Analisis Kinerja dan Perencanaan Keuangan Perusahaan. Yogyakarta: Gramedia Pustaka Utama.

Sudana. (2011). Manajemen Keuangan dan Teori Praktik Perusahaan. Jakarta: Erlangga.

Suguono dan Untung. (2016). Analisa Laporan Keuangan. Jakarta: Grasindo.

Umayta, Irnanda Khabilah. Diana, Nur. dan Afifudin. (2019). Pengaruh Cash Turnover, Receivable Turnover dan Inventory Turnover terhadap Return on Assets Perusahaan Properti yang terdaftar di BEI Periode 2015-2017. E-JRA. Fakultas Ekonomi dan Bisnis Universitas Islam Malang. 08(04). http://riset.unisma.ac.id/index.php/jra/article/download/2397/2244

Yudiana. (2013). Pokok-pokok Manajemen Keuangan. Medan: Ombak.

Yuniastuti, Rina M. (2016). Pengaruh Dominan Cash Ratio dan Debt to Equity terhadap Return on Assets pada Perusahaan Transportasi di Bursa Efek Indonesia. Jurnal Manajemen Magister Darmajaya. 2(01). 95-104. 